\title{
Effect of UV-C Irradiation on Quality from Fresh Grapes var. Bordô
}

\author{
Luiza Siede Kuck ${ }^{1}$ \\ https://orcid.org/0000-0002-7859-0026
}

Caciano Pelayo Zapata Noreña ${ }^{1^{*}}$

https://orcid.org/0000-0002-1618-6802

${ }^{1}$ Federal University of Rio Grande do Sul, Institute of Food Science and Technology, Porto Alegre, Rio Grande do Sul, Brazil.

Editor-in-Chief: Alexandre Rasi Aoki

Associate Editor: Luiz Gustavo Lacerda

Received: 2020.11.21; Accepted: 2021.06.27.

*Correspondence: czapatan@ufrgs.br; Tel.: +55-51-33086673 (C.P.Z.N.)

\section{HIGHLIGHTS}

- The samples irradiated showed losses of bioactive compounds;

- UV-C treatment delayed the softening of the grapes;

- The color of grapes did not change due to irradiation.

\begin{abstract}
The effect of irradiation through UV-C on the content of phenolic compounds, antioxidant activity, color, and texture profile was evaluated in Bordô variety grapes. Grapes were subjected to stress by irradiation at time of $0.5,1.0,4.0,10$ and 30 min that correspond at doses of $0.1,0.3,1.0,2.4$, and $7.2 \mathrm{~kJ} \mathrm{~m}$ ${ }^{2}$, respectively. The total phenolic and anthocyanins content, antioxidant activity, color and texture of the grapes were evaluated after storage at $22{ }^{\circ} \mathrm{C}$ for 24 and $48 \mathrm{~h}$. In general, samples irradiated did not show an increase in total phenolic content, anthocyanin compounds and antioxidant activity. Hue and Chroma values indicated that the color of grapes did not change when irradiated. Texture profile analysis suggested that UV$\mathrm{C}$ treatment delayed grapes softening.
\end{abstract}

Keywords: polyphenols; texture; color; anthocyanins; antioxidant activity.

\section{INTRODUCTION}

The American grape variety (Vitis labrusca L.) is widely cultivated in Brazil and represents more than 80 $\%$ of the grapes used for the production of juices, table wines, and other products, and the most cultivated varieties, such as Bordô, Concord, and Isabel, represent more than $50 \%$ of the national production $[1,2]$. Bordô grapes present the highest content of polyphenols when compared to other grape varieties [1].

Plants may undergo biotic stress, due to the presence of insects, fungi and bacteria, for example, or abiotic stress, which can be either physical (light and temperature) or chemical [3]. When the plants are submitted to any of these stresses, there is an increase in the production of secondary metabolites, such as polyphenols. These compounds have antioxidant activity, which means that due to their redox potential, they 
can act as donors of hydrogen or electrons and as chelating agents of metallic ions, preventing free radicals generation [4].

Under stress conditions, such as UV irradiation, a series of metabolic events are triggered, involving a wide variety of compounds related to fruit quality. Modification of transcription of key genes in the activation or repression of transcription of other genes, such as those related to fruit quality, is believed to occur [5]. This result in the increased activity of phenolic compounds synthesis due to the increase of the enzymatic activities involved in the process, especially phenylalanine ammonia lyase (PAL) $[6,7]$.

Several studies showed that UV-C irradiation increases the content of polyphenols, especially resveratrol, in several grapes varieties such as Napoleon [8], Tempranillo, Cabernet Sauvignon, Merlot, Syrah, Monastrell, Garnacha, Carignan [9], Orion, Regent, Graciano, Palomino, Tintilla de Rota [10], Beta [11], among others. However, there are no studies on the effect of UV-C irradiation on Bordô grapes. This way, the aim of this study was to evaluate the effect of postharvest UV-C irradiation of Bordô grapes on the polyphenols and total anthocyanins contents, antioxidant activity, color, and texture. The interactive effect of UV-C and storage time at $22{ }^{\circ} \mathrm{C}$ also was studied.

\section{MATERIAL AND METHODS}

\section{Materials}

Grapes (Vitis labrusca, Bordo variety) were obtained directly from the producer in the city of Cotiporã, Rio Grande do Sul, Brazil (geographic coordinates: latitude $28^{\circ} 59^{\prime} 38^{\prime \prime}$ S; longitude $51^{\circ} 41^{\prime} 45^{\prime \prime} \mathrm{W}$, altitude $411 \mathrm{~m}$ ) in February 2014. Elapsed time from post-harvest to the reception in the laboratory was approximately 18 hours. DPPH (2,2-diphenyl-1-picrylhydrazyl), Trolox (6-hydroxy-2,5,7,8-tetramethylchroman-2-carboxylic acid), neocuproine and gallic acid were purchased from Sigma-Aldrich, Saint Louis, Missouri. All other reagents used were of analytical grade.

\section{UV-C Postharvest Treatment}

The grapes were received, selected, washed and then physically-chemically characterized. The grape clusters were distributed in an irradiation chamber and irradiated using 4 UV lamps of 30W, at a distance of $40 \mathrm{~cm}$. The grapes were irradiated according to the recommendations of Gonzáles-Barrio and coauthors [12], which consists of irradiating homogeneously on both sides of the bunches. Irradiation times used were 0.5 , $1.0,4.0,10$, and $30 \mathrm{~min}$ that correspond at doses of $0.1,0.3,1.0,2.4$, and $7.2 \mathrm{~kJ} \mathrm{~m}^{-2}$, respectively $[13,14]$. Finally, grapes were stored on trays in an incubator chamber (411 / FDP, Ethik Technology) at $22^{\circ} \mathrm{C}[12,15]$. Some unirradiated clusters were kept in the incubator as a control. Samples were analyzed after 24 and 48 $\mathrm{h}$ of storage [13]. All analysis were performed in triplicate.

\section{Extraction of Bioactive Components}

The extraction of the bioactive compounds was performed according to Cantos and coauthors [16]. One gram of crushed peel was mixed with $4 \mathrm{~mL}$ of methanol: formic acid $(97: 3 ; \mathrm{v} / \mathrm{v})$ solution, remaining at rest for $60 \mathrm{~min}$ in the absence of light. After that, the samples were centrifuged (Thermo, 16R, Thermo Scientific) at $5,000 \times \mathrm{g}$ for $5 \mathrm{~min}$ under refrigeration $\left(4^{\circ} \mathrm{C}\right)$ and filtered using Whatman № 01 filter paper. The grape peel extract was diluted 1:25 (v/v) in the $\mathrm{MeOH}$ : formic acid solution $(97: 3 ; \mathrm{v} / \mathrm{v})$. The reason to use only grape peel is due to skin grape was in higher contact with UV-C radiation, such as realized by several researchers $[12,13,15,17]$.

\section{Determination of Total Phenols}

The total phenols were determined using the Folin-Ciocalteau colorimetric method [18] and the readings were performed in a spectrophotometer (Genesys S10, Thermo Scientific) at $765 \mathrm{~nm}$. The results were expressed as $\mathrm{g} \mathrm{kg}^{-1}$ of sample on a dry basis (d.b) of gallic acid (GAE).

\section{Determination of Total Monomeric Anthocyanins}

Total monomeric anthocyanins were determined according to Lee and coauthors [19]. The absorbance

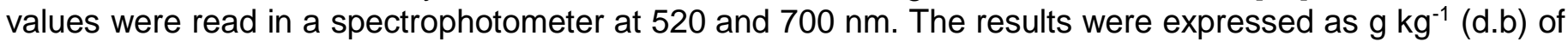
malvidin-3-glycoside (molar absorptivity of $28,000 \mathrm{~L} \mathrm{~cm}^{-1} \mathrm{~mol}^{-1}$ and molar mass of $724.5 \mathrm{~g} \mathrm{~mol}^{-1}$ ). 


\section{Determination of Antioxidant Activity}

The antioxidant activity of the samples was determined by DPPH radical scavenging activity and cupric ion reducing antioxidant capacity (CUPRAC) assays. DPPH was performed according to Brand-Williams and coauthors [20]. The extract was diluted in $\mathrm{MeOH}$ : formic acid $(97: 3 ; \mathrm{v} / \mathrm{v})$ solution at ratio of $1: 15(\mathrm{v} / \mathrm{v})$. Following, $0.1 \mathrm{~mL}$ of the diluted extract was mixed with $3.9 \mathrm{~mL}$ of $60 \mu \mathrm{M}$ DPPH methanolic solution. The absorbance was measured in a spectrophotometer at $515 \mathrm{~nm}$ after $3 \mathrm{~h}$. A Trolox standard curve was elaborated, and the results were expressed as mmol of Trolox equivalent (TE) per $\mathrm{kg}$ of sample on a dry basis (d.b). The antioxidant activity by the CUPRAC method [21] was performed using the extract diluted in $\mathrm{MeOH}$ : formic acid (97:3; v/v) solution at the ratio of 1:25 v/v. A Trolox standard curve was constructed, and the results were expressed as $\mathrm{mmol} \mathrm{kg}^{-1}$ (d.b) of Trolox equivalent (TE).

\section{Colorimetric Analysis}

The color was measured by a colorimeter (CR400/410, Minolta) using the CIE $L^{*} a^{*} b^{*}$ system, where $L^{*}$ indicates lightness $(0=$ black and $100=$ white $), a^{*}$ and $b^{*}$, indicate colors from red $\left(-a^{*}\right)$ to green $\left(+a^{*}\right)$ and from blue $\left(-b^{*}\right)$ to yellow $\left(+b^{*}\right)$, respectively [22]. From $a^{*}$ and $b^{*}$ values, hue angle (Hue $=\tan ^{-1} b^{*} / a^{*}$, which indicates the color of the sample of $0^{\circ}$ or $360^{\circ}=$ red, $90^{\circ}=$ yellow, $180^{\circ}=$ green, $270^{\circ}=$ blue) and Chroma $\left(\right.$ Chroma $\left.=\left[a^{\star 2}+b^{\star 2}\right]^{1 / 2}\right)$, which indicates sample purity or saturation, were calculated [22].

\section{Texture Analysis}

In order to evaluate the possible grape texture variations, texture was measured with a texturometer (TAXT Plus Texture), with the following parameters: load cell $(5 \mathrm{~kg})$, pre-test speed $\left(1.0 \mathrm{~mm} \mathrm{~s}^{-1}\right)$, test speed $(1.5$ $\left.\mathrm{mm} \mathrm{s}^{-1}\right)$, post-test speed $\left(10.00 \mathrm{~mm} \mathrm{~s}^{-1}\right)$, distance $(6.0 \mathrm{~mm})$, trigger force $(5.0 \mathrm{~g})$ and P2 probe $(2 \mathrm{~mm}$ diameter). From the force curves as a function of the resulting distance, the parameters FR (N) (maximum force of rupture required for puncture of the grape skin), and DR $(\mathrm{mm})$ (deformation at the rupture point), were obtained from the grape bark.

\section{Statistical Analysis}

The data were submitted to ANOVA statistical analysis and treatments to Tukey's multiple comparison tests using SAS 9.3 software.

\section{RESULTS AND DISCUSSION}

\section{Bioactive Compound Content and Antioxidant Activity}

Total monomeric phenols and anthocyanins contents in Bordô grapes were $25.45 \pm 0.16\left(\mathrm{~g} \mathrm{~kg}^{-1} \mathrm{~d} . \mathrm{b}\right.$ of gallic acid) and $17.42 \pm 0.11$ ( $\mathrm{g} \mathrm{kg}^{-1} \mathrm{~d} . \mathrm{b}$ of malvidin-3-glycoside), respectively. The antioxidant activity measured by DPPH and CUPRAC was $101.16 \pm 1.27$ and $178.04 \pm 0.96 \mathrm{mmol} \mathrm{kg}^{-1} \mathrm{~d} . \mathrm{b}$ of Trolox, respectively.

Phenols and anthocyanins contents in the grapes on different times of irradiation during storage are shown in Figure 1.

For total phenolic content, after $24 \mathrm{~h}$ of storage, no significant differences were found between the control and the irradiated grapes for $4 \mathrm{~min}$, but in the other treatments the contents were significantly lower, with losses of $25.3,21.8,24.6$ and $25.7 \%$ for the irradiation times of $0.5,1.0,10$ and 30 min, respectively. After $48 \mathrm{~h}$ of storage, the phenolic contents increased in all the treatments, being significantly higher in the control and irradiated grapes for 0.5 and $4.0 \mathrm{~min}$. Despite the increase, the losses were 20.8, 15.8 and $12.9 \%$ for exposure times of 1.0, 10 and 30 min, respectively. Mijowska and coauthors [23] reported a decrease in the polyphenol content during fermenting red grape juice caused by the decomposition of anthocyanins during exposure time in a UV-C reactor at $15 \mathrm{~W}$. Besides, UV-C may also induce an increase in enzymatic activity of polyphenol oxidase and peroxidase that catalyze the oxidation of phenolic compounds resulting on melanin formation [12]. A different behavior to our results was reported by Guerrero and coauthors [10] who found higher content of total polyphenols in wine made from irradiated grapes than in wine made from non-irradiated grapes, but Pala and Toklucu [24] found no significant difference in total phenol content and antioxidant activity of juices produced with white and red grapes with and without irradiation. 

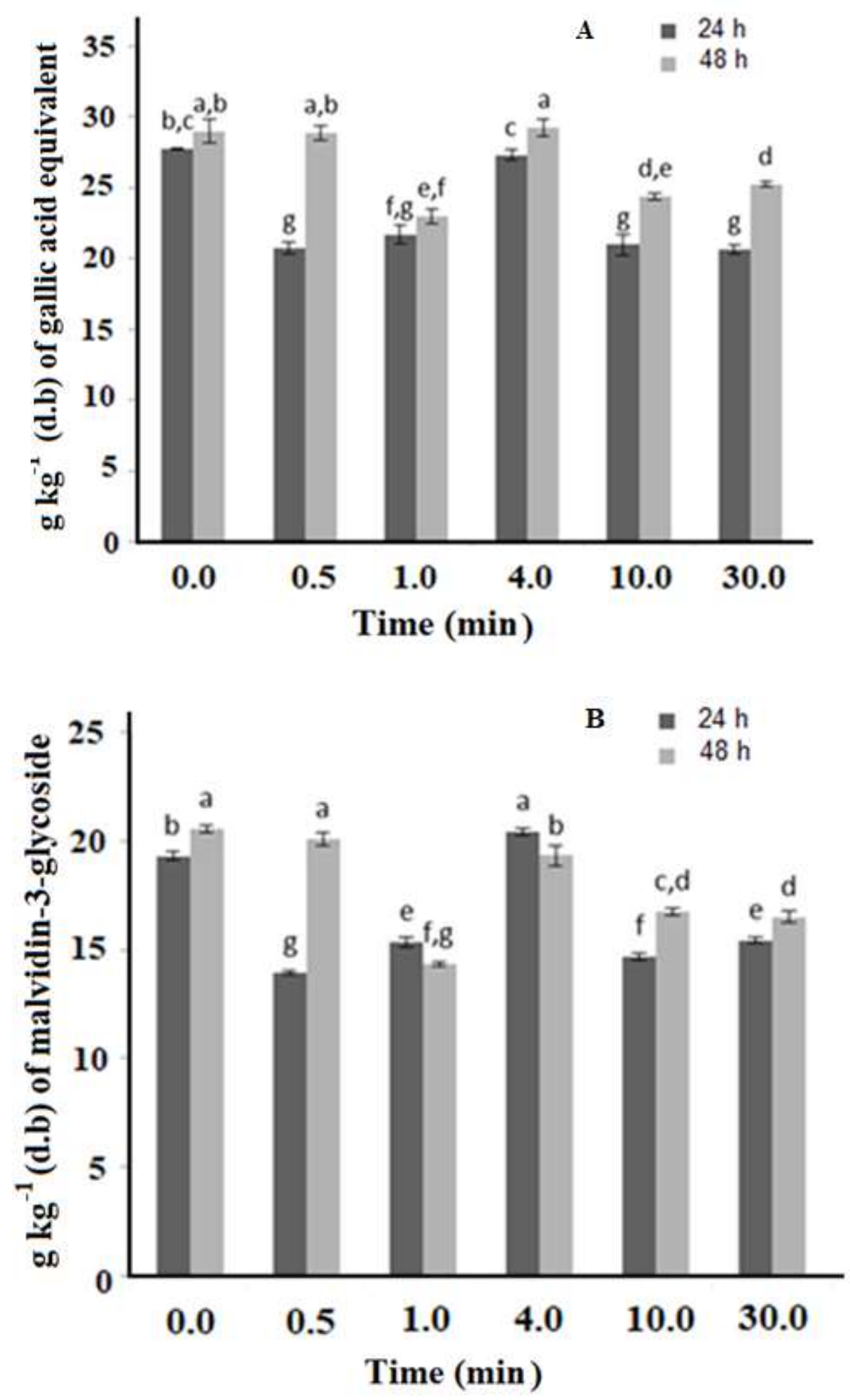

Figure 1. Total phenolic compounds $(A)$ and total monomeric anthocyanin content $(B)$ from Bordô grapes irradiated with UV-C for $0,0.5,1,4,10$ and $30 \mathrm{~min}$, after 24 and $48 \mathrm{~h}$ of storage at $22{ }^{\circ} \mathrm{C}$.

Several studies have demonstrated the increase in polyphenols and resveratrol contents after different grape varieties being irradiated with UV-C. Napoleon variety grapes were irradiated at $90 \mathrm{~W}$ for 30 min [8]; Tempranillo, Cabernet Sauvignon, Merlot, Syrah, Monastrell, Garnacha, and Carriñena grapes suffered irradiation at $510 \mathrm{~W}$ for $30 \mathrm{~s}$ [9]; and Orion, Regent, Merlot, Syrah, Graciano, Tempranillo, Palomino, Tintilla de Rota grapes were irradiated at $510 \mathrm{~W}$ for $60 \mathrm{~s}$ [10], resulting in increases in the levels of phenols or resveratrol from two to ten times. However, studies with the Bordô variety have not been published yet. In addition, most of the studies used irradiation powers higher than $120 \mathrm{~W}$. 
The low performances found by treatments used might be due to low irradiation powers used. Further, UV-C radiation has low penetration power [25]. On the other hand, Alothman and coauthors [14] explain that during irradiation, may happen the oxidation of some antioxidant groups that provide antioxidant capacity.

There are several factors that may be responsible for the Bordô grape variety behavior. Not all types of polyphenols are induced by UV radiation synthesis, and the main induced class is stilbenes. According to Liu and coauthors [11], the synthesis capacity of stilbenes may be activated by exogenous stress factors, however, it depends on the plant genotype. Cantos and coauthors [16] also noted that the maximum induction content of resveratrol depends on the grape variety. According to Siemann and Creasy [26] geographical origin, which includes factors such as soil and climate, are linked to resveratrol synthesis. In addition, the authors point out that differences in induction of stilbene synthesis may be linked to agronomic factors as well as the degree of maturation.

The level of fruit maturation may be one of the main factors associated with the behavior observed in our study. The synthesis of resveratrol is catalyzed by stilbene synthase which uses p-coumaroyl-CoA and malonyl-CoA as substrates, as well as chalcone synthase uses the same substrates for the production of chalcone, which is a precursor of flavonoids [27,6]. As the degree of maturity increases, competition between stilbene synthase and chalcone synthase occurs; this may reduce the levels of some compounds in grapes, such as resveratrol, and increase the accumulation of others, such as some types of anthocyanins [28].

However, grape berries gradually lose their stilbene synthesis potential as they approach maturity [29]. The expression of flavonoid pathway genes is also dependent on the ripening phase of the grape [30]. Thus, a very advanced stage of ripening and a possible reduction in PAL enzyme content may have prevented the increase of fruit enzymatic activity, and consequently the competition between stilbene and anthocyanin production.

Another possible factor of influence is the color of the grape, which according to Cantos and coauthors [16], resveratrol synthesis is not linked to grape color, however, Guerrero-Beltrán and coauthors [31] suggest that the strong violet color of the grape may block or decrease the penetration of UV light in grape juice. The Bordeaux grape is known to have very intense coloration. The $L^{*}$ values determined in the colorimetric analysis were below 32 , which indicates the tendency to black.

The decrease in anthocyanin content in the present study behaved similarly to the reduction in total phenol content. At $24 \mathrm{~h}$ of storage, the highest anthocyanin content was found for treatment with 4 min of irradiation. The losses of irradiated grapes for 0.5, 1, 10 and 30 min were 27.7, 20.5, 24 and $20.2 \%$, respectively. At $48 \mathrm{~h}$ of storage, all treatments had lower values than the control, except for the irradiated grapes for $0.5 \mathrm{~min}$, which did not differ significantly from this one. The irradiated grapes for $1,4,10$ and 30 min showed losses of 30.2, 6, 18.4 and $19.8 \%$, respectively. Bakowska and coauthors [32] observed that UV light causes strong degradation of non-copigmented anthocyanins, and that copigmentation is an alternative to prevent their degradation. Cantos and coauthors [8] observed a reduction in anthocyanin content in irradiated grapes compared to control, however the reduction was not significant. The results found in the determination of antioxidant activity measured by DPPH and CUPRAC for the different irradiation times are shown in Figure 2.

In general, higher antioxidant activity was observed by CUPRAC than by DPPH, which was already observed by other authors who applied these two methods to the same sample [33]. Not all antioxidant methods and sources are known to be compatible, and the same antioxidant species may produce different results in different trials [34]. The variation of results found between different methods of antioxidant activity occurs due to factors such as the solubility of the extracts in the different test systems [35] and the inequalities in characteristics and reaction mechanisms, which causes that no trial accurately reflects all sources of radicals or all antioxidants in a mixed or complex system [36], such as fruit extracts. 

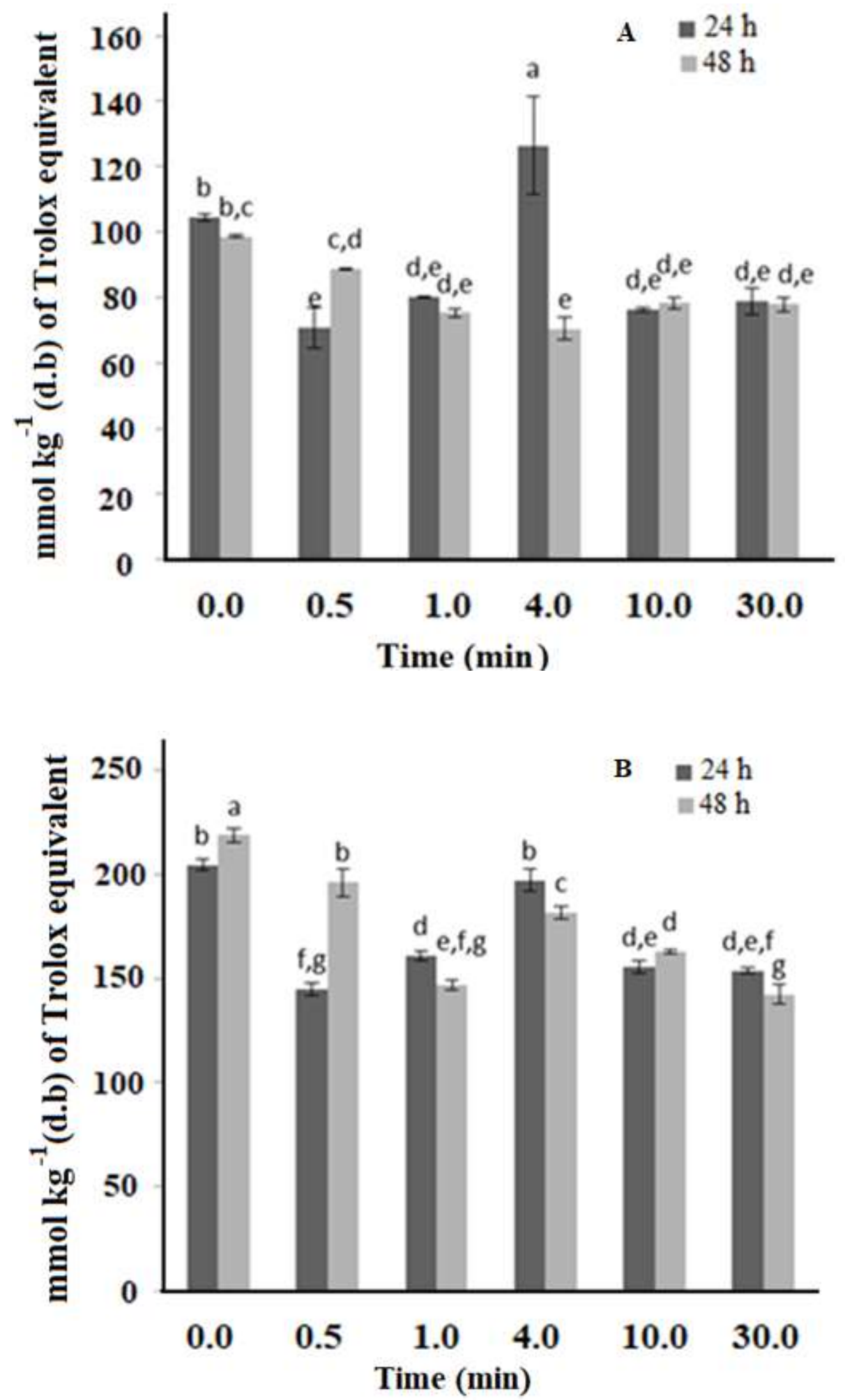

Figure 2. Antioxidant activity by DPPH (A) and CUPRAC (B) from Bordô grapes irradiated with UV-C for $0,0.5,1,4,10$ and $30 \mathrm{~min}$, after 24 and $48 \mathrm{~h}$ of storage at $22^{\circ} \mathrm{C}$.

At $24 \mathrm{~h}$ of storage, except for the $4 \mathrm{~min}$ irradiated sample that was significantly larger than the control, all irradiated samples had lower DPPH antioxidant activity than the control. However, after $48 \mathrm{~h}$, the antioxidant activity of the irradiated sample for $4 \mathrm{~min}$ dropped by $44.2 \%$, reaching values significantly lower than the control and irradiated grapes for $0.5 \mathrm{~min}$. In this regard, Sheng and coauthors [37] mention that grapes treated at $3.6 \mathrm{~kJ} \mathrm{~m}^{-2}$ and storage at $4 \stackrel{\circ}{\circ}$, flavonoid contents rapidly raised, and then fastly decreased in $21 \mathrm{~d}$. They consider that a tricky process of biosynthesis occurs due to several conditions of postharvest and storage that arouse these changes of total flavonoid content during storage. When using the CUPRAC method, grapes irradiated for 4 min did not differ significantly from the control at $24 \mathrm{~h}$ of storage, and after 48 
$\mathrm{h}$, the antioxidant activity of the control was superior to that of all treatments. Although both methods use a single-electron donation mechanism, the fractions of the phenolic compounds from peel grape that act as antioxidants for these two chromogenic radicals ABTS ${ }^{+}$(measured at $734 \mathrm{~nm}$ ) and DPPH. (measured at 515 $\mathrm{nm}$ ) may not have been the same. For this reason, the difference between the results obtained [38,39].

The behavior of the antioxidant activity for irradiated grapes was similar to that of phenols and anthocyanins, which was expected since these compounds confer the antioxidant activity to the grapes. Pala and Toklucu [24] did not observe significant differences in the antioxidant activity of juices produced with UV$C$ irradiated and non-irradiated grapes. However, according to Alothman and coauthors [14], who evaluated the effect of UV-C irradiation on banana, pineapple and guava, the reduction in antioxidant activity may be attributed to the oxidation that may occur during treatment of some antioxidant groups that contribute significantly to antioxidant activity.

High doses of UV-C or UV-B rays may lead to overproduction of reactive oxygen species (ROS) and the development of oxidative stress [40], which may eventually reduce antioxidant activity. Other authors tested the influence of UV-C radiation on polyphenol standard solutions and plant extracts, observing degradation in both after a certain irradiation time, with reductions of 15 to $85 \%$ [41]. Murugesan and coauthors [42] observed increase and decrease in the content of phenolic compounds of UV-C treated elderberry, depending on the time of application.

Thus, the production of ROS by UV-C rays may end up reducing antioxidant activity, as a consequence of the reduction of phenolic compounds, which will immediately act to combat these formed radicals. So, if the level of fruit maturation is too advanced, compromising the intensification of the activity of the enzymes that synthesize the polyphenols, there will be no replacement of them, nor an increase in their content.

\section{Grape Color Assessment}

Color parameters $\left(L^{*}, a^{*}, b^{*}\right.$, Hue and Chroma) of the treatments are shown in Table 1.

As for the parameter $L^{*}$, the values were close to 30 , indicating samples with tendency to black. At $24 \mathrm{~h}$ of storage there was a significant difference between the control and the irradiated sample for $10 \mathrm{~min}$. At 48 $\mathrm{h}$ of storage there was no significant difference between irradiated and control grapes.

Parameters $a^{*}$ and $b^{*}$ were negative for all treatments, indicating the direction of the color from green to blue, and Hue values were between 243 and $257^{\circ}$, close to $270^{\circ}$ which is the angle that represents the blue color. The blue color is provided by the presence of some types of anthocyanins, the most important being malvidin-3-glycoside [43], which is the monomeric anthocyanin present in most grapes [44].

Chroma values were close to 0 , which indicates low color saturation. This is due to the fact that the color was measured directly on the fruit peel, where several other components such as pigments are contained. There was no significant difference between samples for parameters $b^{*}$, Hue and Chroma. Several authors have reported little or no change in the color of UV-C irradiated grapes or the juices produced from them in relation to their respective controls [8,31]. Mijowska and coauthors [23] also reported that although of changing in polyphenols and anthocyanins contents, UV-C exposure did not affect the color of fermenting grape juice.

\section{Grape Texture Assessment}

The evaluated texture parameters are shown in Table 2. $F_{R}$ corresponds to the bark resistance to probe penetration [45]. After $24 \mathrm{~h}$ of storage, it can be observed that the irradiated grapes for the times of 0.5 and $10 \mathrm{~min}$ had $\mathrm{F}_{\mathrm{R}}$ values higher than the control, while the other samples did not differ significantly from it. However, when 24 and $48 \mathrm{~h}$ of storage were compared, the force of rupture significantly decreased in the control sample, whereas for the same treatment, except for the treatment of $4 \mathrm{~min}$, there were no significant differences. Fava and coauthors [46] reported that after UV-C irradiation in grapes Vitis labrusca var. Isabella, $F_{R}$ values increased from 4.9 to 5.4. The bark has an important role on the mechanical properties of the fruit, contributing with more than $80 \%$ of the firmness before reaching the point of rupture [46]. 
Table 1. Parameters of the color of grapes var. Bordô, irradiated by UV-C at different times and control after 24 and 48 h of storage at $22^{\circ} \mathrm{C}$.

\begin{tabular}{|c|c|c|c|c|c|}
\hline & $L^{*}$ & $a^{*}$ & $b^{*}$ & Hue & Chroma \\
\hline Initial sample & $29.41 \pm 1.77^{a . b}$ & $-0.21 \pm 0.11^{a . b}$ & $-1.13 \pm 0.49^{a}$ & $250.03 \pm 3.02^{\mathrm{a}}$ & $1.15 \pm 0.50^{a}$ \\
\hline \multicolumn{6}{|c|}{$24 \mathrm{~h}$} \\
\hline Control & $31.38 \pm 0.68^{a}$ & $-0.45 \pm 0.11^{b}$ & $-1.71 \pm 0.47^{a}$ & $244.97 \pm 4.62^{\mathrm{a}}$ & $1.77 \pm 0.46^{a}$ \\
\hline $0.5 \mathrm{~min}$ & $28.76 \pm 0.56^{a . b}$ & $-0.05 \pm 0.05^{a}$ & $-1.44 \pm 0.85^{\mathrm{a}}$ & $257.50 \pm 2.18^{a}$ & $1.44 \pm 0.85^{\mathrm{a}}$ \\
\hline $1 \mathrm{~min}$ & $28.90 \pm 1.24^{\text {a.b }}$ & $-0.20 \pm 0.09^{a . b}$ & $-1.77 \pm 0.63^{a}$ & $252.82 \pm 4.69^{a}$ & $1.78 \pm 0.62^{a}$ \\
\hline $4 \mathrm{~min}$ & $29.17 \pm 1.09$ a.b & $-0.22 \pm 0.12^{a . b}$ & $-1.42 \pm 0.36^{\mathrm{a}}$ & $251.39 \pm 3.24^{a}$ & $1.43 \pm 0.37^{a}$ \\
\hline $10 \mathrm{~min}$ & $28.04 \pm 0.91^{b}$ & $-0.20 \pm 0.13^{a . b}$ & $-1.06 \pm 0.35^{a}$ & $248.70 \pm 6.72^{a}$ & $1.08 \pm 0.35^{\mathrm{a}}$ \\
\hline $30 \mathrm{~min}$ & $28.96 \pm 1.03^{a . b}$ & $-0.16 \pm 0.07^{a}$ & $-0.98 \pm 0.29^{a}$ & $250.45 \pm 2.30^{a}$ & $1.08 \pm 0.35^{\mathrm{a}}$ \\
\hline \multicolumn{6}{|c|}{$48 \mathrm{~h}$} \\
\hline Control & $28.13 \pm 1.52^{b}$ & $-0.30 \pm 0.08^{a . b}$ & $-1.31 \pm 0.31^{a}$ & $246.54 \pm 5.37^{a}$ & $1.34 \pm 0.30^{\mathrm{a}}$ \\
\hline $0.5 \mathrm{~min}$ & $27.63 \pm 0.78^{b}$ & $-0.21 \pm 0.15^{a . b}$ & $-1.08 \pm 0.55^{a}$ & $243.05 \pm 20.63^{a}$ & $1.13 \pm 0.49^{a}$ \\
\hline $1 \mathrm{~min}$ & $28.86 \pm 0.83^{a . b}$ & $-0.17 \pm 0.11^{a}$ & $-1.77 \pm 0.63^{a}$ & $253.89 \pm 4.53^{a}$ & $1.78 \pm 0.63^{a}$ \\
\hline $4 \min$ & $28.62 \pm 0.67^{b}$ & $-0.21 \pm 0.05^{a . b}$ & $-1.41 \pm 0.31^{a}$ & $251.55 \pm 1.92^{\mathrm{a}}$ & $1.43 \pm 0.31^{\mathrm{a}}$ \\
\hline $10 \mathrm{~min}$ & $27.77 \pm 1.39^{b}$ & $-0.22 \pm 0.15^{a . b}$ & $-1.53 \pm 0.58^{a}$ & $252.50 \pm 2.61^{a}$ & $1.54 \pm 0.60^{\mathrm{a}}$ \\
\hline $30 \mathrm{~min}$ & $28.71 \pm 0.70^{b}$ & $-0.14 \pm 0.12^{\mathrm{a}}$ & $-1.57 \pm 0.62^{\mathrm{a}}$ & $254.71 \pm 3.43^{a}$ & $1.58 \pm 0.63^{a}$ \\
\hline
\end{tabular}

Different letters in the same column indicate significant differences $(p<0.05)$.

Data represents the mean and standard deviation.

Regarding the $D_{R}$ parameter, which measures the deformation at the maximum force point, none of the treatments differed significantly from the control. The results obtained were higher than those found by Fava and coauthors [46] on grapes Vitis labrusca Isabella variety with and without irradiation, which were 6.5 and 6.0 respectively. These differences may be due to the degree of ripeness, species and variety, as fruit ripening produces softening, characterized by changes in pulp texture during storage, attributed to the degradation of the structures of the primary cell wall and middle lamella, which are influenced by degradative enzymes such as polygalacturonase, pectinesterase, and cellulose $[47,48]$. In addition, UV-C radiation in the range from 0.7 to $4.0 \mathrm{~kJ} \mathrm{~m}^{-2}$ on figs displayed neither speeding up nor delay effects from its ripening [49].

The behavior observed in this work suggests a delay in the softening process by UV-C irradiation. According to Pombo and coauthors [50], UV-C irradiation of strawberries decreases the transcription of a set of genes involved in cell wall degradation during the first $h$ after treatment, consequently, reducing the softening of tissues. 
Table 2. The maximum force of rupture $\left(\mathrm{F}_{\mathrm{R}}, \mathrm{N}\right)$ required to puncture the skin of the grape, and the deformation $\left(\mathrm{D}_{\mathrm{R}}, \mathrm{mm}\right)$ produced at the point of rupture of the skin of grapes var. Bordô, irradiated by UV-C at different times and control after 24 and $48 \mathrm{~h}$ of storage at $22^{\circ} \mathrm{C}$.

\begin{tabular}{lll}
\hline Treatment & $\mathbf{F}_{\mathbf{R}}(\mathbf{N})$ & $\mathbf{D}_{\mathbf{R}}(\mathbf{m m})$ \\
\hline Initial sample & $3.44 \pm 0.29^{\mathrm{d}, \mathrm{e}}$ & $9.74 \pm 1.21^{\mathrm{a}, \mathrm{b}}$ \\
\hline Control & $\mathbf{2 4} \mathbf{h}$ & \\
\hline $\mathbf{0 . 5}$ min & $3.74 \pm 0.19^{\mathrm{a}, \mathrm{b}, \mathrm{c}, \mathrm{d}}$ & $8.98 \pm 2.07^{\mathrm{a}, \mathrm{b}}$ \\
$\mathbf{1}$ min & $4.02 \pm 0.06^{\mathrm{a}, \mathrm{b}}$ & $9.14 \pm 0.83^{\mathrm{a}, \mathrm{b}}$ \\
$\mathbf{4}$ min & $3.48 \pm 0.09^{\mathrm{d}, \mathrm{e}}$ & $8.63 \pm 0.74^{\mathrm{a}, \mathrm{b}}$ \\
$\mathbf{1 0}$ min & $3.55 \pm 0.21^{\mathrm{c}, \mathrm{d}, \mathrm{e}}$ & $8.78 \pm 0.57^{\mathrm{a}, \mathrm{b}}$ \\
$\mathbf{3 0}$ min & $3.92 \pm 0.13^{\mathrm{a}, \mathrm{b}, \mathrm{c}}$ & $7.38 \pm 1.67^{\mathrm{b}}$ \\
& $3.69 \pm 0.09^{\mathrm{a}, \mathrm{b}, \mathrm{c}, \mathrm{d}}$ & $8.14 \pm 1.36^{\mathrm{a}, \mathrm{b}}$ \\
\hline Control & $\mathbf{4 8} \mathbf{h}$ & \\
\hline $\mathbf{0 . 5}$ min & $3.23 \pm 0.19^{\mathrm{e}}$ & $8.20 \pm 0.94^{\mathrm{a}, \mathrm{b}}$ \\
$\mathbf{1}$ min & $3.66 \pm 0.03^{\mathrm{b}, \mathrm{c}, \mathrm{d}}$ & $8.80 \pm 0.99^{\mathrm{a}, \mathrm{b}}$ \\
$\mathbf{4}$ min & $3.48 \pm 0.15^{\mathrm{c}, \mathrm{d}, \mathrm{e}}$ & $8.98 \pm 1.00^{\mathrm{a}, \mathrm{b}}$ \\
$\mathbf{1 0}$ min & $3.92 \pm 0.11^{\mathrm{a}, \mathrm{b}}$ & $10.06 \pm 0.50^{\mathrm{a}}$ \\
$\mathbf{3 0}$ min & $4.00 \pm 0.25^{\mathrm{a}}$ & $7.82 \pm 0.90^{\mathrm{a}, \mathrm{b}}$ \\
\hline
\end{tabular}

Different letters in the same column indicate significant differences $(p<0.05)$.

Data represents the mean and standard deviation

\section{CONCLUSION}

In spite of several studies indicating that UV-C irradiation increases the polyphenols content of several grape varieties, the results obtained in this study showed that the same did not occur with the Bordô variety. In general, the samples irradiated showed losses of bioactive compounds, and consequently, a decrease in the antioxidant activity. On the other hand, the color characteristics were not affected. Regarding the texture, the results suggested a delay in the softening of the grapes treated with UV-C. Further studies should be performed to better evaluate the behavior of the Bordô grape against UV-C irradiation, in less advanced ripening stages and under higher irradiation conditions, as well as to identify the profile of phenolic compounds after irradiation exposure.

Funding: The authors thank Fundação de Amparo à Pesquisa do Estado do Rio Grande do Sul (FAPERGS), Conselho Nacional de Desenvolvimento Científico e Tecnológico (CNPQ) and Coordenação de Aperfeiçoamento de Pessoal de Nível Superior (CAPES) for financial support.

Conflicts of Interest: The authors declare no conflict of interest.

\section{REFERENCES}

1. Burin VM, Ferreira-Lima NE, Panceri CP, Bordignon-Luiz MT. Bioactive compounds and antioxidant activity of Vitis vinifera and Vitis labrusca grapes: Evaluation of different extraction methods. Microchem J. 2014; 114: 155-63.

2. Lago-Vanzela ES, Da-Silva R, Gomes E, García-Romero E, Hermosín-Gutiérrez I. Phenolic Composition of the Edible Parts (Flesh and Skin) of Bordô Grape (Vitis labrusca) Using HPLC-DAD-ESI-MS/MS. J Agric Food Chem. 2011; 59: 13136-46.

3. Hopkins WG, Hüner NPA. Introduction to plant physiology. 4th ed. New Jersey: John Wiley \& Sons Inc. 2008. 503p.

4. Salah N, Miller NJ, Paganga G, Tijburg L, Bolwell GP, Rice-Evans C. Polyphenolic flavanols as scavengers of aqueous phase radicals and as chain-breaking antioxidants. Arch Biochem Biophys. 1995; 322: 339-46.

5. Vom Endt D, Kijne JW, Mamelink J. Transcription factors controlling plant secondary metabolism: what regulates the regulators? Phytochem. 2002; 61: 107-14.

6. Fritzemeier $\mathrm{KH}, \mathrm{Kindl} \mathrm{H}$. Coordinate induction by UV light of stilbene synthase, phenylalanine ammonia-lyase and cinnamate 4-hydroxylase in leaves of Vitaceae. Planta. 1981; 151: 48-52.

7. Pombo MA, Rosli HG, Martínez GA, Civello PM. UV-C treatment affects the expression and activity of defense genes in strawberry fruit (Fragaria $x$ ananassa, Duch.). Postharvest Biol Technol. 2011; 59: 94-102. 
8. Cantos E, García-Viguera C, Pascual-Teresa S, Tomás-Barberán FA. Effect of postharvest ultraviolet irradiation on resveratrol and other phenolics of Cv. Napoleon Table Grapes. J Agric Food Chem. 2000; 48: 4606-12.

9. Cantos E, Tomás-Barberán T, Martínez A, Espín JC. Differential stilbene induction susceptibility of seven red wine grape varieties upon post-harvest UV-C irradiation. Eur Food Res Technol. 2003; 217: 253-8.

10. Guerrero RF, Puertas B, Fernández ML, Palma M, Cantos-Villar E. Induction of stilbenes in grapes by UV-C: Comparison of different subspecies of Vitis. Innov Food Sci Emerg Technol. 2010; 11: 231-8.

11. Liu W, Liu C, Yang C, Wang L, Li S. Effect of grape genotype and tissue type on callus growth and production of resveratrols and their piceids after UV-C irradiation. Food Chem. 2010; 122: 475-81.

12. Gonzáles-Barrio R, Salmenkallio-Marttila M, Tomás-Barberán FA, Cantos E, Espín JC. Etiology of UV-C-Induced browning in Var. Superior white table grapes. J Agric Food Chem. 2005; 53: 5990-6.

13. Crupi P, Pichierri A, Basile T, Antonacci D. Postharvest stilbenes and flavonoids enrichment of table grape cV Redglobe (Vitis vinifera L.) as affected by interactive UV-C exposure and storage conditions. Food Chem. 2013; 141: 802-8.

14. Alothman M, Bhat R, Karim AA. UV irradiation-induced changes of antioxidant capacity of fresh-cut tropical fruits. Innov Food Sci Emerg Technol. 2009; 10: 512-6.

15. González-Barrio R, Beltrán D, Cantos E, Gil MI, Espín JC, Tomás-Barberán, F.A. Comparison of ozone and UV-C treatments on the postharvest stilbenoid monomer, dimer, and trimer induction in Var. 'Superior' white table grapes. J Agric Food Chem. 2006; 54: 4222-8.

16. Cantos E, Espín JC, Tomás-Barberán FA. Postharvest stilbene-enrichment of red and White table grape varieties using UV-C irradiation pulses. J Agric Food Chem. 2002; 50: 6322-9.

17. Guerrero, RF, Puertas B, Fernández MI, Piñeiro Z, Cantos-Villar E. UVC-treated skin-contact effect on both white wine quality and resveratrol content. Food Res Int. 2010; 43: 2179-85.

18. Singleton VL, Rossi JA. Colorimetry of total phenolics with phosphomolybdic-phosphotungstic acid reagents. Am J Enol Vitic. 1965; 16: 144-58.

19. Lee J, Durst RW, Wrolstad RE. Determination of total monomeric anthocyanin pigment content of fruit juices, beverages, natural colorants, and wines by the $\mathrm{pH}$ differential method: collaborative study. J AOAC Int. 2005; 88: 1269-78.

20. Brand-Williams W, Cuvelier ME, Berset C. Use of free radical method to evaluate antioxidant activity. LWT - Food Sci Technol. 1995; 28: 25-30.

21. Apak R, Güçlü K, Özyürek M, Karademir SE. Novel total antioxidant capacity index for dietary polyphenols and vitamins $\mathrm{C}$ and $\mathrm{E}$, using their cupric ion reducing capability in the presence of neocuproin: CUPRAC method. J Agric Food Chem. 2004; 52: 7970-81.

22. Bakker J, Bridle P, Timberlake CF. Tristimulus measurements (CIELAB 76) of port wine colour. Vitis. 1986; 25: 6778.

23. Mijowska K, Cendrowski, K, Grygorcewicz, B, Oszmiański J, Nawrotek P, Ochmian I, Zielińska B. Preliminary study on the influence of UV-C irradiation on microorganism viability and polyphenol compounds content during winemaking of 'Regent' red grape cultivar. Polish J Chem Technol. 2017; 19: 130-7.

24. Pala Ç, Toklucu AK. Effects of UV-C light processing on some quality characteristics of grape juices. Food Bioprocess Tech. 2013; 6: 719-25.

25. Esua OJ, Chin NL, Yusof, YA, Sukor, R. Effects of simultaneous UV-C radiation and ultrasonic energy postharvesttreatment on bioactive compounds and antioxidant activity of tomatoesduring storage. Food Chem. 2019; 270: 113-22.

26. Siemann EH, Creasy LL. Concentration of the phytoalexin resveratrol in wine. Am J Enol Vitic. 1992;43:49-52.

27. Chong J, Poutaraud A, Hugueney P. Metabolism and roles of stilbenes in plants. Plant Sci. 2009;177:143-55.

28. Jeandet $P$, Sbaghi $M$, Bessis R, Meunier $P$. The potential relationship of stilbene (resveratrol) synthesis to anthocyanin content in grape berry skins. Vitis. 1995; 34: 91-4.

29. Keller M, Steel CC, Creasy GL. Stilbene accumulation in grapevine tissues: Developmental and environmental effects. Acta Hort. 2000; 514: 275-86.

30. Boss PK, Davies C, Robinson SP. Expression of anthocyanin biosynthesis pathway genes in red and white grapes. Plant Mol Biol. 1996; 32: 565-9.

31. Guerrero-Beltrán JA, Welti-Chanes J, Barbosa-Cánovas GV. Ultraviolet-C light processing of grape, cranberry and grapefruit juices to inactivate saccharomyces cerevisiae. J Food Process Eng. 2009; 32: 916-32.

32. Bakowska A, Kucharska AZ, Oszmianski J. The effects of heating, UV irradiation, and storage on stability of the anthocyanin-polyphenol copigment complex. Food Chem. 2003; 81: 349-55.

33. Meng JF, Fang YL, Qin MY, Zhuang XF, Zhang ZW. Varietal differences among the phenolic profiles and antioxidant properties of flour cultivars of spine grape (Vitis davidii Foex) in Chongyi (China). Food Chem. 2012; 134: 2049-56. 
34. Craft BD, Kerrihard AL, Amarowicz R, Pegg RB. Phenol-based antioxidants and the in vitro methods used for their assessment. Compr Rev Food Sci Food Saf. 2012; 11: 148-73.

35. Zhu YP, Fan JF, Cheng YQ, Li LT. Improvement of the antioxidant activity of Chinese traditional fermented okara (Meitauza) using Bacillus subtilis B2. Food Control. 2008; 19: 654-61.

36. Prior RL, Wu X, Schaich K. Standardized methods for the determination of antioxidant capacity and phenolics in foods and dietary supplements. J Agric Food Chem. 2005; 53: 4290-302.

37. Sheng K, Zheng H, Shui S, Yan L, Liu C, Zheng L. Comparison of postharvest UV-B and UV-C treatments on table grape: Changes in phenolic compounds and their transcription of biosynthetic genes during storage. Postharvest Biol Technol. 2018; 138, 74-81.

38. Kwon SH, Wang Z, Hwang SH, Kang, Y, Lee J, Lim SS. Comprehensive evaluation of the antioxidant capacity of Perilla frutescens leaves extract and isolation of free radical scavengers using step-wise HSCCC guided by DPPHHPLC. Int J Food Prop. 2017; 20, S921-S34

39. Abramovič H, Grobin B, Ulrih NP, Cigić B. Relevance and Standardization of In Vitro Antioxidant Assays: ABTS, DPPH, and Folin-Ciocalteu. J Chem. 2018; ID 4608405

40. Katerova Z, Todorova D, Tasheva K, Sergiev I. Influence of ultraviolet radiation on plant secondary metabolite production. Genet Plant Physiol. 2012; 2: 113-44.

41. Volf I, Ignat I, Neamtu M, Popa VI. Therma stability, antioxidant activity, and photo-oxidation of natural polyphenols. Chem Pap. 2014; 68: 121-9.

42. Murugesan $R$, Orsat $V$, Lefsrud $M$. Effect of pulsed ultraviolet light on the total phenol content of elderberry (Sambucus nigra) fruit. Food Nutr Sci. 2012; 3: 774-83.

43. Schwartz SJ, Von Elbee JH, Giusti MM. Colorants. In: Damodaran S, Parkin KL, Fennema OR. (Eds.). Fennema's Food Chem. 2010. (571-638), 4th ed. Taylor and Francis ed.

44. Amico V, Napoli EM, Renda A, Ruberto G, Spatafora C, Tringali C. Constituents of grape pomace from Sicilian cultivar 'Nerello Mascalese'. Food Chem. 2004; 88: 599-607.

45. Segade SR, Rolle L, Gerbi V, Orriols I. Phenolic ripneness assessment of grape skin by texture analysis. J Food Compos Anal. 2008; 21: 644-9.

46. Fava J, Hodara K, Nieto A, Guerrero S, Alzamora SM, Castro MA. Structure (micro, ultra, nano), color and mechanical properties of Vitis labrusca L. (grape berry) fruits treated by hydrogen peroxide, UV-C irradiation and ultrasound. Food Res Int. 2011; 44: 2938-48.

47. Gao P, Zhu Z, Zhang P. Effects of chitosan-glucose complex on postharvest quality and shelf life of table grapes. Carbohyd Polym. 2013; 95: 371-8.

48. Yang Z, Zheng Y, Cao S, Tang S, Ma S, Li N. Effects of storage temperature on textural properties of Chinese bayberry fruit. J Texture Stud. 2007; 38: 166-77.

49. Usberti, FCS, Ferraz, ACO. UV-C radiation on fresh fig quality. Sci Agric. 2021; 78: 1-5.

50. Pombo MA, Dotto MC, Martínez GA, Civello PM. 2009. UV-C irradiation delays strawberry fruit softening and modifies the expression of genes involved in cell wall degradation. Postharvest Biol Technol. 2009; 51: 141-8.

(C) 2021 by the authors. Submitted for possible open access publication under the terms and conditions of the Creative Commons Attribution (CC BY NC) license (https://creativecommons.org/licenses/by-nc/4.0/). 